\section{Aminoethoxyvinylglycine Treatment of Peach Fruit Reduces Ethylene Production and Softening}

\author{
Robert D. Belding ${ }^{1}$ and Gail R.W. Lokaj ${ }^{2}$ \\ Cook College, Rutgers University, Rutgers Agricultural Research and Extension \\ Center, 121 Northville Road, Bridgeton, NJ 08302
}

Additional index words. Prunus persica, soluble solids, woolliness, maturity delay, fruit firmness

\begin{abstract}
Biscoe' and 'Encore' peach [Prunus persica (L.) Batsch] trees were treated in two years with AVG at 7, 14, or 21 days before first harvest (DBFH) or as a nontreated control (NTC). Fruit were harvested every 2 to 3 days based on observed initial yielding of fruit flesh and ground color. Fruit were further evaluated for maturity and quality based on the production of ethylene, ground color, diameter, flesh firmness, soluble sugars, and woolliness. Evaluations occurred 1 day after harvest and after 14 and 28 days in cold storage. AVG applications delayed early harvests of 'Biscoe', but 'Encore' harvests were not affected. Across all preharvest treatment timings, AVG reduced ethylene production by $64 \%$. Ethylene production and fruit softening were most inhibited for fruit treated with AVG 7 DBFH. In this study, fruit treated with AVG demonstrated a significant negative correlation between fruit ethylene production and firmness. Average flesh firmness of fruit from AVG treatments were 11.8 Newtons greater than NTC fruit. Fruit treated 21 or 14 DBFH exhibited greener ground color than NTC fruit or fruit treated 7 DBFH. The NTC fruit had the highest ground color values, fruit treated 7 DBFH were intermediate, and fruit treated 21 or $14 \mathrm{DBFH}$ had the lowest values for ground color. AVG has potential use as a management tool for controlling the timing of harvest and for allowing fruit to ripen more slowly and to hang longer on the tree, thus improving fruit size. In addition, AVG assists in maintaining the postharvest flesh firmness required to withstand handling during marketing. Chemical name used: aminoethoxyvinylglycine (AVG).
\end{abstract}

As peach fruit mature, flesh firmness rapidly declines, resulting in a narrow harvest window and short postharvest shelf life. Harvesting stone fruit in a more mature stage can add significantly to fruit size and flavor, but severely compromises the potential shelf life because fruits are softer and more prone to bruising. Since market price is mainly determined by size, large fruits that are firmer with good flavor would be more profitable.

Ethylene is a naturally produced gaseous plant growth regulator that stimulates fruit senescence, including fruit softening caused by the synthesis of cell wall degradation enzymes such as polygalacturonase, synthesis of pigment such as lycopene, production of aromatic volatiles that enhance fruit flavor, and stimulates the degradation of both chlorophyll and starch. Stored starch can then be converted into simple sugars as part of the ripening process.

AVG is a plant growth regulator that blocks the conversion of 1 aminocyclopropane-1-

Received for publication 1 Oct. 2001. Accepted for publication 23 Jan. 2002. Research was supported in part by the New Jersey Agricultural Experiment Station of Rutgers Univ. Use of trade names does not imply endorsement of the products named nor criticism of similar ones not named.

${ }^{1}$ Assistant Extension Specialist in Pomology, Rutgers Agricultural Research and Extension Center, 121 Northville Road, Bridgeton, NJ 08302. E-mail address: belding@aesop.rutgers.edu

${ }^{2}$ Program Associate. carboxylic acid (ACC) from methionine, a precursor of ethylene, and thereby halts ethylene production (Yu and Yang, 1979). AVG applied to apple fruit $30 \mathrm{~d}$ prior to normal harvest maturity at a rate of $124 \mathrm{~g} \cdot \mathrm{ha}^{-1}$ a.i. (50 $\mathrm{g} / \mathrm{acre}$ a.i.) delayed fruit ripening, reduced premature fruit drop, reduced preharvest and postharvest fruit softening, reduced water core, and increased fruit removal force (Autio and Bramlage 1982; Bangerth 1978; Williams 1980). Early spring AVG applications to peach trees delayed tree development and bloom up to $10 \mathrm{~d}$ and fruit were firmer at harvest (Dekazos, 1981).

Exogenous ethylene stimulates ripening and senescence of some fruit and is used commercially to ripen bananas. AVG treatments block the production of ethylene, but do not act to block the action of exogenous ethylene. Tonutti et al. (1991) regulated cold room ethylene, but found that it did not affect fruit quality or firmness of nectarines kept for 20 and $40 \mathrm{~d}$. In a more direct application, Byers (1997) treated peaches to a 60-s postharvest dip of AVG prior to storage, which reduced fruit softening and reduced ethylene production to nondetectable levels. Fruit sprayed preharvest with AVG were only slightly delayed in harvest maturity (Byers, 1997).

Maturity indices of peach fruit that had the highest correlations with sensory evaluations by a trained panel include flesh firmness of the cheek and blossom end, as well as color at- tributes of the peach skin (Brovelli et al., 1998). Skin color attributes can be assessed nondestructively, and are therefore useful as predictive measures of fruit maturity (Bible and Singha, 1993; Delwiche and Baumgardner, 1985).

Woolliness is an internal postharvest disorder of stone fruit increased by improper storage temperatures where damage occurs to flesh causing reduced juiciness of the fruit (Crisosto et al., 1999). Woolliness is a major postharvest disorder, limiting shelf life and broader marketing of stone fruit. The purpose of this study was to evaluate the effects of preharvest AVG application timing on peach fruit maturity and ethylene production, as well as the effects on postharvest flesh firmness retention and woolliness.

\section{Materials and Methods}

This study was conducted in 1999 and 2000, using 12-13-year-old 'Biscoe' and 'Encore' trees, at the Rutgers Fruit Research Center, Cream Ridge, N.J. Trees were treated with $50 \mathrm{~g}$ a.i. of AVG formulated as ReTain, (Valent Biosciences Corp., Libertyville, Ill.) in $379 \mathrm{~L}$ ( $100 \mathrm{gal})$ of water plus $0.05 \% \mathrm{v} / \mathrm{v}$ of organosilicone surfactant Silwet L-77, using a handgun sprayer. Four single tree replicates of each cultivar, arranged in a randomized complete-block design, were treated 21,14 , or $7 \mathrm{~d}$ before first harvest (DBFH). A set of nontreated control trees (NTC) was included. Thirty-two trees were used in all. In 1999, trees were hand-thinned to commercial level. In 2000, a spring frost limited the crop to $\approx 75 \%$ of commercial level, without hand thinning.

In order to determine maturity and minimize variability, fruit were harvested at a stage of maturity much softer than would be commercially feasible. Fruit needed to be nondestructively selected for harvest based on a uniformly definable stage of maturity. The simplest criterion for selecting fruit to be harvested with suitable accuracy was the first perception of flesh giving way readily to pressure. Each fruit at each sample date was firmly grasped, if the fruit yielded slightly, it was detached from the tree and recorded. Since perception of firmness is somewhat subjective, in order to minimize variability, it was viewed important that the same evaluators performed all harvest determinations with each evaluator having equal selection influence at each experimental unit.

Fruit were harvested five to seven times over 14 to $21 \mathrm{~d}$, as fruit reached a predetermined stage of maturity as previously described. Since treatment and weather affects can introduce added variability to fruit maturation and quality, it is important to select fruit for postharvest quality evaluations from a single harvest date when sufficient quantities of uniformly mature fruit are available.

Selected fruits were subdivided into three samples of 10 representative fruit. Ground color determinations were done on all fruit sets immediately following harvest. Fruit ground color is an indicator of fruit maturity used commercially for harvest determination. 
Peach fruit ground color was quantified, where the fruit was least affected by red overcolor, by a Minolta CM 508d spectrophotometer (Minolta, Ramsey, N.J.) with an 8-mm aperture and a $10^{\circ}$ angle illuminating viewing geometry (Voss 1992). The spectrophotometer was calibrated before each session using a white tile and void space. Measurements were taken from a spot on the fruit where there was the least interference from the red blush overcolor. The results are reported as the CIELAB color coordinate $\mathrm{a}^{*}$ (pronounced A-star), which is the measure of blue-green to red-purple with green being a more negative and red being a more positive value (Bible and Singha, 1993: McGuire 1992). CIE refers to the Commission Internationale de l'E Clairage (International Commission on Ilumination).

One 10-fruit subsample was evaluated one day following harvest, and two additional replicate samples were promptly stored at $0{ }^{\circ} \mathrm{C}$ for 14 or $28 \mathrm{~d}$. Fruit quality evaluations, as described below, were performed in the same manner for samples whether just harvested or following 14 or $28 \mathrm{~d}$ storage. Fruit samples were held at room temperature $\left(20^{\circ} \mathrm{C}\right)$ overnight prior to evaluation. Nondestructive evaluations of weight, ethylene production, and diameter were then performed prior to destructive evaluations of flesh firm- ness, soluble solids, and woolliness determination.

Ethylene production was determined by gas chromatography, individually on five preweighed fruit from each of the 10 fruit samples. In both years of this study, fruit ethylene was measured $1 \mathrm{~d}$ following harvest, and additionally in 2000, following 2 and 4 weeks of storage. One-milliter headspace gas samples from each jar were quantified using a Schimadzu GC model 14a (Kyoto, Japan) equipped with a FID detector operating isothermally at $100{ }^{\circ} \mathrm{C}$ through a Pora pak Q (Waters Corp., Milford, Mass.) column with nitrogen as the carrier gas.

Flesh firmness of each fruit was determined by removing a small piece of skin from opposite sides of the peach at right angles to the suture and inserting a McCormick Fruit Pressure Tester (Yakima, Wash.) equipped with a 7.9-mm stone fruit tip (Kader and Mitchell, 1989). Fruit flesh firmness, in conjunction with size and appearance, affects market life and value of stone fruit. Fruit were selected for harvest based on uniform firmness. Initial flesh firmness assessments were delayed 24 to $36 \mathrm{~h}$ from actual harvest to allow for the completion of nondestructive measurements.

Fruit diameters, soluble solids, and woolliness were determined and recorded for each fruit. Diameters were measured directly with a steel diameter tape equatorially around each fruit. Soluble solids were determined by extracting a small flesh sample from the suture line of each fruit and applying expressed juice to an Atago refractometer model PR-1 (Atago Co., Japan) calibrated with water. Woolliness was subjectively rated, by the same evaluator, on a scale of 1 to 3 , where 1 had normal juice expressed, 2 had no juice expressed (woolly), or 3, where the flesh expressed no juice and woolliness was most extreme. Ethylene is normally associated with ripening and fruit senescence, however work by Dong et al. (2001) recently associated the ethylene blocking compound MCP with increased woolliness and decreased healthy fruit of 'Flavor Top' nectarine. In this work, the presence of ethylene during storage decreased woolliness and increased the percentage of healthy fruit.

Data were recorded and analyzed by SAS using the GLM procedure or Pearson's correlation analysis (SAS Institute, Cary, N.C.). Statistical separation of the means was reported using the Waller-Duncan $\mathrm{k}$ ratio $t$ test and regression analysis produced Pearson's correlation coefficients. All data were recorded on 10 fruit per replicate set, except for the ethylene analysis where only five fruit were sampled per replicate set.

Table 1. Yield of 'Biscoe' and 'Encore' peach by date of harvest recorded as a percent of the total treatment yield as affected by AVG treatments. Treatments include $50 \mathrm{~g}$ a.i. of AVG per $379 \mathrm{~L}$ of water applied 21, 14, or $7 \mathrm{~d}$ before first harvest $(\mathrm{DBFH})$, and the nontreated control.

\begin{tabular}{|c|c|c|c|c|c|c|c|}
\hline \multirow[b]{2}{*}{ Julian date } & \multicolumn{5}{|c|}{ Yield (\%) Biscoe 1999} & & \\
\hline & $\begin{array}{c}\text { Harvest } 1 \\
238\end{array}$ & $\begin{array}{c}\text { Harvest } 2 \\
243\end{array}$ & $\begin{array}{c}\text { Harvest } 3 \\
246\end{array}$ & $\begin{array}{c}\text { Harvest } 4 \\
251\end{array}$ & $\begin{array}{c}\text { Harvest } 5 \\
253\end{array}$ & & \\
\hline \multicolumn{8}{|l|}{ Treatment } \\
\hline Control & $49.5^{z} a^{y}$ & $25.9 \mathrm{NS}$ & $15.4 \mathrm{ab}$ & $4.2 \mathrm{NS}$ & $5.0 \mathrm{NS}$ & & \\
\hline $21 \mathrm{DBFH}$ & $7.5 \mathrm{~b}$ & 34.0 & $22.0 \mathrm{ab}$ & 20.7 & 15.8 & & \\
\hline 14 DBFH & $11.6 \mathrm{~b}$ & 25.6 & $34.0 \mathrm{a}$ & 11.8 & 17.0 & & \\
\hline \multirow[t]{3}{*}{7 DBFH } & $46.6 \mathrm{a}$ & 19.1 & $3.5 \mathrm{~b}$ & 5.6 & 25.2 & & \\
\hline & \multicolumn{5}{|c|}{ Yield (\%) Biscoe 2000} & & \\
\hline & Harvest 1 & Harvest 2 & Harvest 3 & Harvest 4 & Harvest 5 & & \\
\hline Julian date & 231 & 235 & 238 & 242 & 245 & & \\
\hline \multicolumn{8}{|l|}{ Treatment } \\
\hline Control & $22.5 \mathrm{~b}$ & $25.7 \mathrm{ab}$ & $21.6 \mathrm{NS}$ & $17.7 \mathrm{NS}$ & $12.5 \mathrm{NS}$ & & \\
\hline $21 \mathrm{DBFH}$ & $18.7 \mathrm{~b}$ & $14.3 \mathrm{~b}$ & 21.4 & 24.0 & 21.6 & & \\
\hline $14 \mathrm{DBFH}$ & $30.4 \mathrm{~b}$ & $34.5 \mathrm{a}$ & 7.2 & 12.8 & 15.1 & & \\
\hline $7 \mathrm{DBFH}$ & $48.7 \mathrm{a}$ & $5.1 \mathrm{~b}$ & 9.2 & 20.1 & 16.9 & & \\
\hline \multicolumn{8}{|c|}{ Yield (\%) Encore 1999} \\
\hline & Harvest 1 & Harvest 2 & Harvest 3 & Harvest 4 & Harvest 5 & Harvest 6 & Harvest 7 \\
\hline Julian date & 252 & 256 & 260 & 264 & 267 & 271 & 274 \\
\hline \multicolumn{8}{|l|}{ Treatment } \\
\hline Control & $20.6^{z} \mathrm{NS}^{y}$ & $64.1 \mathrm{Ns}$ & $13.4 \mathrm{NS}$ & $1.9 \mathrm{NS}$ & 0 NS & $0 \mathrm{NS}$ & $0 \mathrm{NS}$ \\
\hline $21 \mathrm{DBFH}$ & 3.9 & 65.0 & 29.5 & 1.6 & 0 & 0 & 0 \\
\hline $14 \mathrm{DBFH}$ & 5.3 & 43.6 & 32.4 & 15.9 & 2.4 & 0.4 & 0 \\
\hline $7 \mathrm{DBFH}$ & 13.6 & 36.6 & 22.9 & 15.2 & 85.9 & 0 & 5.8 \\
\hline \multicolumn{8}{|c|}{ Yield (\%) Encore 2000} \\
\hline & Harvest 1 & Harvest 2 & Harvest 3 & Harvest 4 & Harvest 5 & Harvest 6 & Harvest 7 \\
\hline Julian date & 242 & 245 & 250 & 252 & 256 & 259 & 264 \\
\hline \multicolumn{8}{|l|}{ Treatment } \\
\hline Control & $6.7 \mathrm{NS}$ & $27.2 \mathrm{NS}$ & $36.3 \mathrm{NS}$ & $16.0 \mathrm{NS}$ & $12.3 \mathrm{NS}$ & $1.5 \mathrm{NS}$ & $0 \mathrm{NS}$ \\
\hline $21 \mathrm{DBFH}$ & 1.0 & 13.6 & 35.6 & 16.6 & 16.3 & 11.1 & 5.9 \\
\hline $14 \mathrm{DBFH}$ & 1.4 & 21.7 & 44.9 & 18.3 & 13.7 & 0 & 0 \\
\hline $7 \mathrm{DBFH}$ & 5.7 & 21.0 & 41.8 & 17.2 & 11.8 & 1.9 & 0.6 \\
\hline
\end{tabular}

${ }^{\mathrm{z}}$ Means were of four single tree replications.

${ }^{\mathrm{y}}$ Mean separation within columns by Waller-Duncan k ratio $t$ test; $P<0.05$.

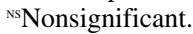




\section{Results and Discussion}

Effects of the timing of the AVG application on fruit maturity are seen in the yield of mature fruit over the harvest period (Table 1). In all four harvests (two seasons and two cultivars), nontreated fruit and fruit treated with AVG 7 DBFH yielded the highest percentage of fruit judged mature for sampling at the first harvest, indicating advanced maturity. Yield of fruit treated with AVG 14 or 21 DBFH were smaller at the first harvest, indicating that maturity was delayed. In 1999, the first harvest was very small where AVG was applied 14 or $21 \mathrm{DBFH}$ and is considered negligible (Table 1). In 1999, 49\% of nontreated 'Biscoe' fruit were judged mature at the first harvest, compared to only $7.5 \%$ and $11.6 \%$ of the fruit treated with AVG at 21 or $14 \mathrm{DBFH}$, respectively (Table 1). 'Biscoe' fruit treated 7 DBFH reached sampling maturity with or before NTC fruit. There was no delay of sampling maturity when treatments were delayed to $7 \mathrm{DBFH}$, only when treatments were applied earlier. The result was that AVG applied at 14 or $21 \mathrm{DBFH}$ delayed, but did not extend the harvest window, resulting in a delayed harvest of a greater portion of the total yield among each cultivar and year. AVG treated fruit followed the same trend regardless of cultivar or year. Fruit treated earlier delayed harvest more than the later AVG application timings. In all four harvests (two seasons and two cultivars), AVG applied $21 \mathrm{DBFH}$ delayed harvest more than applications at 14 DBFH. Further, fruit that were not treated until 7 DBFH continued to mature the longest among AVG treatments and therefore fruit developed to the threshold for harvest sooner than fruit treated earlier.

When the percent of the crop harvested was plotted against time, $50 \%$ of the control fruit reached crop sampling maturity $4.2 \mathrm{~d}$ before $50 \%$ of fruit treated $21 \mathrm{DBFH}$. Likewise, fruit treated $7 \mathrm{DBFH}$ reached $50 \%$ of the crop harvested 2.9 d before fruit treated 21 DBFH.

Except for four harvest dates of 'Biscoe' fruit, most harvests had no statistical differences in the percent of yield due to AVG treatment. Yield analysis revealed that the frost had thinned the 2000 crop by only $23 \%$ from $169 \mathrm{~kg}$ in 1999 to $130 \mathrm{~kg}$ in 2000. It was not determined if this difference in yield had an affect on fruit maturity or quality.

All AVG treatments significantly reduced peach ethylene production. Averaged over all AVG treatments, ethylene production was reduced by over $64 \%$, from $0.087 \mu \mathrm{L} \cdot \mathrm{g}^{-1}$ per min for nontreated fruit to an average of 0.029 $\mu \mathrm{L} \cdot \mathrm{g}^{-1}$ per min for AVG treated fruit (Table 2 ). AVG applied 7 and 14 DBFH lowered fruit ethylene production significantly at harvest and the effect was sustained throughout every postharvest sampling compared to NTC fruit (Table 2). The greatest reduction in ethylene production occurred on fruit sprayed $7 \mathrm{DBFH}$. The reduction of ethylene production as a result of AVG treatment timing was sustained throughout 4 weeks of storage. The effect of AVG treatments on ethylene production lasted all 7 weeks of the study, from the $21 \mathrm{DBFH}$ treatments through 4 weeks of postharvest storage.

There were consistent inversely correlated relationships between ethylene production and flesh firmness. Correlation analysis of fruit ethylene production, ground color as $\mathrm{a}^{*}$, and flesh firmness had very consistent results across harvests of both cultivars for both years (Table 3). Consistently, ethylene production was negatively correlated to firmness. Also, ethylene production was positively correlated to the CIELAB value recorded for ground color. Ground color was always negatively correlated to fruit firmness. The fact that AVG treatments applied closer to harvest had greater effect than earlier treatment timings suggests that not all sites of ethylene production were affected by earlier AVG treatments. It is speculated that sites of ethylene production that developed following treatment circumvented the inhibition.

Table 2. 'Biscoe' and 'Encore' peach flesh firmness, fruit ethylene production, ground color, woolliness rating, and fruit diameter is reported. Treatments include $50 \mathrm{~g}$ a.i. of AVG per $379 \mathrm{~L}$ of water applied 21, 14, or $7 \mathrm{~d}$ before first harvest (DBFH), and the nontreated control. Ethylene production was also measured in 2000 after 2 and 4 weeks of cold storage.

\begin{tabular}{|c|c|c|c|c|c|c|c|c|}
\hline \multirow[b]{4}{*}{ Treatments } & \multicolumn{8}{|c|}{ Ethylene production $\left(\mu \mathrm{L} \cdot \mathrm{g}^{-1}\right.$ per minute $)$} \\
\hline & \multicolumn{4}{|c|}{ Biscoe } & \multicolumn{4}{|c|}{ Encore } \\
\hline & \multirow{2}{*}{$\begin{array}{c}1999 \\
1 \text { day PH }\end{array}$} & \multicolumn{3}{|c|}{2000} & \multirow{2}{*}{$\begin{array}{c}1999 \\
1 \text { day PH }\end{array}$} & \multicolumn{3}{|c|}{2000} \\
\hline & & 1 day $\mathrm{PH}$ & 2 weeks & 4 weeks & & 1 day $\mathrm{PH}$ & 2 weeks & 4 weeks \\
\hline Control & $0.087^{z} \mathrm{a}^{y}$ & $0.071 \mathrm{a}$ & $0.025 \mathrm{a}$ & $0.114 \mathrm{a}$ & $0.139 \mathrm{a}$ & $0.015 \mathrm{a}$ & $0.172 \mathrm{a}$ & $0.026 \mathrm{a}$ \\
\hline $21 \mathrm{DBFH}$ & $0.041 b c$ & $0.043 \mathrm{~b}$ & $0.018 \mathrm{a}$ & $0.075 a b$ & $0.039 \mathrm{~b}$ & $0.007 \mathrm{~b}$ & $0.076 \mathrm{~b}$ & $0.014 \mathrm{~b}$ \\
\hline 14 DBFH & $0.057 \mathrm{~b}$ & $0.025 b c$ & $0.006 \mathrm{~b}$ & $0.029 b c$ & $0.040 \mathrm{~b}$ & $0.008 \mathrm{~b}$ & $0.078 \mathrm{~b}$ & $0.006 \mathrm{~b}$ \\
\hline \multirow[t]{4}{*}{$7 \mathrm{DBFH}$} & $0.024 \mathrm{c}$ & $0.012 \mathrm{c}$ & $0.007 \mathrm{~b}$ & $0.010 \mathrm{c}$ & $0.030 \mathrm{~b}$ & $0.005 \mathrm{~b}$ & $0.044 \mathrm{~b}$ & $0.007 \mathrm{~b}$ \\
\hline & \multicolumn{8}{|c|}{ Flesh firmness (Newtons) } \\
\hline & \multicolumn{4}{|c|}{ Biscoe } & \multicolumn{4}{|c|}{ Encore } \\
\hline & 1999 & & 2000 & & 1999 & & 2000 & \\
\hline Treatments & 1 day $\mathrm{PH}$ & 1 day $\mathrm{PH}$ & 2 weeks & 4 weeks & 1 day $\mathrm{PH}$ & 1 day $\mathrm{PH}$ & 2 weeks & 4 weeks \\
\hline Control & $7.3^{y} c^{x}$ & $32.3 \mathrm{~d}$ & $44.0 \mathrm{c}$ & $20.6 \mathrm{~d}$ & $16.4 \mathrm{c}$ & $76.1 \mathrm{c}$ & $27.0 \mathrm{~b}$ & $41.7 \mathrm{~b}$ \\
\hline $21 \mathrm{DBFH}$ & $14.4 \mathrm{~b}$ & $48.1 \mathrm{c}$ & $54.6 \mathrm{~b}$ & $32.9 \mathrm{c}$ & $26.6 \mathrm{~b}$ & $84.7 \mathrm{ab}$ & $18.4 \mathrm{~b}$ & $49.9 \mathrm{a}$ \\
\hline 14 DBFH & $11.3 \mathrm{~b}$ & $57.4 \mathrm{~b}$ & $64.1 \mathrm{a}$ & $47.3 \mathrm{~b}$ & $30.3 \mathrm{ab}$ & $79.7 \mathrm{bc}$ & $25.4 \mathrm{~b}$ & $50.0 \mathrm{a}$ \\
\hline \multirow[t]{4}{*}{$7 \mathrm{DBFH}$} & $30.4 \mathrm{a}$ & $63.6 \mathrm{a}$ & $69.3 \mathrm{a}$ & $53.3 \mathrm{a}$ & $33.6 \mathrm{a}$ & $89.3 \mathrm{a}$ & $42.9 \mathrm{a}$ & $53.4 \mathrm{a}$ \\
\hline & \multicolumn{8}{|c|}{ Ground color (CIELAB a*) } \\
\hline & \multicolumn{4}{|c|}{ Biscoe } & \multicolumn{4}{|c|}{ Encore } \\
\hline & 1999 & & 2000 & & 1999 & & 2000 & \\
\hline Treatments & At harvest & At harvest & 2 weeks & 4 weeks & At harvest & At harvest & 2 weeks & 4 weeks \\
\hline Control & $9.20^{y} \mathrm{a}^{\mathrm{x}}$ & $3.07 \mathrm{a}$ & $2.52 \mathrm{a}$ & $3.18 \mathrm{a}$ & $9.01 \mathrm{a}$ & $2.11 \mathrm{a}$ & $3.41 \mathrm{a}$ & $2.37 \mathrm{a}$ \\
\hline $21 \mathrm{DBFH}$ & $5.57 \mathrm{c}$ & $0.65 \mathrm{c}$ & $0.92 \mathrm{~b}$ & $1.05 \mathrm{bc}$ & $5.81 \mathrm{c}$ & $0.26 \mathrm{c}$ & $1.07 \mathrm{~b}$ & $0.26 \mathrm{c}$ \\
\hline 14 DBFH & $7.57 \mathrm{~b}$ & $0.41 \mathrm{c}$ & $0.65 \mathrm{~b}$ & $0.65 \mathrm{c}$ & $5.42 \mathrm{c}$ & $0.53 \mathrm{bc}$ & $0.80 \mathrm{~b}$ & $1.05 \mathrm{bc}$ \\
\hline \multirow[t]{4}{*}{7 DBFH } & $7.59 \mathrm{~b}$ & $1.54 \mathrm{~b}$ & $1.83 \mathrm{a}$ & $1.80 \mathrm{~b}$ & $7.75 \mathrm{~b}$ & $1.39 \mathrm{ab}$ & $1.80 \mathrm{~b}$ & $1.64 \mathrm{ab}$ \\
\hline & \multicolumn{8}{|c|}{ Woolliness (rated 1-3) } \\
\hline & \multicolumn{4}{|c|}{ Biscoe } & \multicolumn{4}{|c|}{ Encore } \\
\hline & 1999 & & 2000 & & 1999 & & 2000 & \\
\hline Treatments & 1 day $\mathrm{PH}$ & 1 day $\mathrm{PH}$ & 2 weeks & 4 weeks & 1 day $\mathrm{PH}$ & 1 day $\mathrm{PH}$ & 2 weeks & 4 weeks \\
\hline Control & $1.08^{y} \mathrm{NS}^{\mathrm{x}}$ & $1.00 \mathrm{NS}$ & $1.10 \mathrm{NS}$ & $1.71 \mathrm{a}$ & $1.03 \mathrm{NS}$ & $1.00 \mathrm{NS}$ & $1.85 \mathrm{NS}$ & $1.36 \mathrm{a}$ \\
\hline $21 \mathrm{DBFH}$ & 1.03 & 1.00 & 1.16 & $1.48 \mathrm{ab}$ & 1.18 & 1.00 & 1.92 & $1.12 \mathrm{~b}$ \\
\hline $14 \mathrm{DBFH}$ & 1.13 & 1.00 & 1.24 & $1.29 \mathrm{~b}$ & 1.21 & 1.00 & 2.05 & $1.26 \mathrm{ab}$ \\
\hline $7 \mathrm{DBFH}$ & 1.00 & 1.00 & 1.16 & $1.37 \mathrm{ab}$ & 1.31 & 1.00 & 1.90 & $1.08 \mathrm{~b}$ \\
\hline
\end{tabular}

${ }^{\mathrm{z}}$ Means were of five fruit for each of four single tree replications.

${ }^{\mathrm{y}}$ Means were of 10 fruit for each of four single tree replications.

${ }^{\mathrm{x}}$ Mean separation within columns by Waller-Duncan $\mathrm{k}$ ratio $t$ test; $(P<0.05)$. NS $=$ nonsignificant. 
Table 3. Correlation analysis of fruit ethylene production, ground color and flesh firmness. Analysis was performed on all fruit sampled within groups sorted by cultivar and year.

\begin{tabular}{|c|c|c|c|c|}
\hline & \multicolumn{2}{|c|}{ Biscoe } & \multicolumn{2}{|c|}{ Encore } \\
\hline & 1999 & 2000 & 1999 & 2000 \\
\hline Ethylene production* flesh firmness & $-0.774^{* *}$ & $-0.802^{* * *}$ & $-0.611^{\text {*** }}$ & $-0.333^{* * *}$ \\
\hline Ethylene production $*$ ground color $\mathrm{a}^{*}$ & $0.316^{* *}$ & $0.432^{* *}$ & $0.259^{*}$ & $0.333^{* *}$ \\
\hline Flesh Firmness $*$ ground color a* & $-0.322^{* *}$ & $-0.429^{* *}$ & $-0.413^{* *}$ & $-0.222^{*}$ \\
\hline
\end{tabular}

*Following the correlation coefficient indicates $<0.05$ Prob $>|\mathrm{r}|$ under HO: Rho $=0$.

${ }^{* * *}$ Indicates $<0.01$.

There was a significant lag period between actual harvest from the tree and the determination of flesh firmness. Nondestructive determination of the timing of fruit maturity for comparison purposes is very difficult because of fruit to fruit variability and the papacy of accurate nondestructive maturity induces. Initial flesh firmness assessments were delayed 24 to $36 \mathrm{~h}$ from actual harvest to allow for the completion of nondestructive measurements. During this time, fruit were held at room temperature and significant changes in flesh softening have likely occurred (Table 2). In both years, 1999 and 2000 for both varieties, nontreated control fruit had the softest flesh firmness measurements $1 \mathrm{~d}$ following harvest (Table 2). 'Biscoe' fruit treated 7 DBFH were an average of $21.3 \mathrm{~N}$ firmer than nontreated fruit the day after harvest. Similarly, 'Encore' fruit treated $7 \mathrm{DBFH}$ were $15.2 \mathrm{~N}$ firmer than the nontreated controls. Averaged across all treatments and sample dates, fruit treated with AVG were $11.8 \mathrm{~N}$ (2.7 lbs.) firmer than nontreated fruit. In 1999, 'Biscoe' fruit were too soft for commercial shipping $24 \mathrm{~h}$ following harvest. Conversely, fruit treated with AVG at 7 or $14 \mathrm{DBFH}$, retained firmness well above market requirements throughout the 4 weeks of postharvest storage of this study.

For both cultivars and both years, flesh firmness was affected by AVG application timing. Fruit treated 7 DBFH were the most firm, while fruit treated 14 or $21 \mathrm{DBFH}$ were intermediate, and the nontreated control was always the least firm (Table 2). Trends of flesh firmness response were consistent throughout this experiment. The last preharvest AVG treatment timing resulted in the firmest fruit $1 \mathrm{~d}$ after harvest. The earliest applications were intermediate and the nontreated fruit were the softest. These trends continued throughout 4 weeks of storage. After 4 weeks in storage, 'Biscoe' fruit treated $7 \mathrm{DBFH}$ averaged $32.7 \mathrm{~N}$ firmer, and 'Encore' fruit, also treated $7 \mathrm{DBFH}$, were $11.8 \mathrm{~N}$ firmer than the associated NTC fruit. Extended storage caused the fruit to have a rubbery texture that was observed following 4 weeks of storage. Fruit had flesh that made initial penetration with the tip of the pressure tester difficult. Peaches with nonmelting flesh are known to develop rubbery flesh textures (Brovelli, 1998).

Ground color is a useful predictor of fruit maturity (Delwiche and Baumgardner, 1985). AVG delayed maturation as measured by ground color (Table 2). AVG applied 21 DBFH resulted in the lowest measured
CIELAB a* value, indicating more green and less mature fruit. Fruit treated 7 DBFH always had the highest measured CIELAB a* value of all AVG-treated fruit. The $7 \mathrm{DBFH}$ treatments were significant, both because the fruit were able to remain on the tree longer and ripen further than other treatments, and this treatment had the strongest suppression of ethylene production resulting in greater fruit firmness at harvest. AVG treated fruit harvests were delayed in maturity as measured by the ground color and firmness. Additionally, NTC fruit had higher ground color values than fruit treated with AVG treatments at 14 or $28 \mathrm{DBFH}$. When the AVG treatment was applied $7 \mathrm{DBFH}$, fruit ripened to a greater extent than fruit treated at 14 or 28 DBFH where the treatment apparently halted fruit maturation. This supports earlier comments that fruit treated 7 DBFH were significantly influenced by maturation that occurred prior to AVG treatment, compared to fruit treated earlier in development. The advanced maturation of the 7 DBFH treated fruit was evident by the higher CIELAB measurements of " $a *$." These fruit were the firmest and considered the most mature fruit from both years and both cultivars (Table 2).

Following 4 weeks in storage, woolliness was reduced in fruit treated with AVG (Table 2). 'Biscoe' fruit treated with AVG $14 \mathrm{DBFH}$ reduced woolliness $25 \%$ following 4 weeks storage. Likewise, woolliness of 'Encore' fruit was reduced by treatments 7 and 21 DBFH by $21 \%$ and $18 \%$, respectively. Woolliness is a disorder that significantly damages fruit marketability and does not appear until after fruit have been stored and are in the ripening period. Since adequate control of postharvest diseases is now attainable, woolliness is currently the major limitation to broader marketing of stone fruit.

In order to commercially ship peaches, they need to be harvested at a firmness level of $\approx 45$ to $55 \mathrm{~N}$ to permit them to arrive at the grocer's shelf in good condition. AVG treatment will allow fruit to hang longer on the tree to improve size and flavor while maintaining fruit firmness. Because of this ability to maintain fruit firmness and internal quality, AVG may be useful for the management of harvest, allowing fruit to gain size without softening, and to improve the postharvest quality of fruit. AVG treatments in this study have demonstrated the inverse relationship between fruit ethylene production and the retention of firmness. This work has also clarified the response of fruit to the timing of preharvest treatments, where applications timed closer to fruit maturity resulted in the greatest reduction of ethylene production, firmer fruit in storage, and the most mature fruit according to ground color determinations. Earlier application timings resulted in fruit with greener ground color, indicating less mature and firmer fruit. From these results, we could predict the earlier AVG application timings to have the strongest effect on reducing fruit maturity, and the latest $A V G$ application timings to have the greatest effect at reducing ethylene production and sustaining postharvest fruit flesh firmness. Work should continue to determine the optimum timing of AVG applications on various stone fruit varieties as well as to determine the optimum application rates.

\section{Literature Cited}

Autio, W.R. and W.J. Bramlage. 1982. Effects of AVG on maturation, ripening, and storage of apples. J. Amer. Soc. Hort. Sci. 107:1074-1077.

Bangerth, F. 1978. The effect of a substituted amino acid on ethylene biosynthesis, respiration, ripening and preharvest drop of apple fruits. J. Amer. Soc. Hort. Sci. 103:401-404.

Bible, B.B. and S. Singha. 1993. Canopy position influences CIELAB coordinates of peach color. HortScience 28:992-993.

Brovelli, E.A., J.K. Brecht, and W.B. Sherman. 1998. Potential maturity indices and developmental aspects of melting-flesh and nonmeltingflesh peach genotypes for the fresh market. J. Amer. Soc. Hort. Sci. 123:438-444.

Byers, R.E. 1997. Peach and nectarine fruit softening following aminoethoxyvinylglycine sprays and dips. HortScience 32:86-88.

Crisosto, C.H., F.G. Mitchell, and Z. Ju. 1999. Susceptibility to chilling injury of peach, nectarine, and plum cultivars grown in California. HortScience 34:1116-1118.

Dekazos, E.D. 1981. Effect of aminoethoxyvinylglycine on bloom delay, fruit maturity, and quality of 'Loring' and 'Rio Oso Gem' peaches. HortScience 16:520-522.

Delwiche, M.J. and R.A. Baumgardner 1985. Ground color as a peach maturity index. J. Amer. Soc. Hort. Sci. 110:53-57.

Dong, L., H.W. Zhou, X. Feng, and S. Lurie. 2001. The role of ethylene in development of storage disorders in nectarine and plum. Acta Hort. (ISHS) 553:285-286.

Kader, A.A and F.G. Mitchell. 1989. Maturity and quality, p. 191-196. In: J.H. LaRue and R.S Johnson (eds.). Peaches, plums, and nectarines growing and handling for fresh market. Publication no. 3331. Publications, Div. of Agr. and Nat. Res., Univ. of California, Oakland.

McGuire, R.G. 1992. Reporting of objective color measurements. HortScience 27:1254-1255.

Tonutti, P., P. Callon, and A. Ramina. 1991. Ethylene biosynthesis during peach fruit development. J. Amer. Soc. Hort. Sci. 116:274-279.

Voss, D.H. 1992. Relating colorimeter measurement of plant color to the Royal Horticultural Society Colour Chart. HortScience 27:1256-1260.

Williams, M.W. 1980. Retention of fruit firmness and increase in vegetative growth and fruit set of apples with aminoethoxyvinylglycine. HortScience 15:76-77.

Yu, Y.B. and S.F. Yang. 1979. Auxin induced ethylene production and its inhibition by aminoethoxyvinylglycine and cobalt ion. Plant Physiol. 64:1074-1077. 